\title{
Blended Learning Analysis for Sports Schools in Indonesia
}

\author{
https://doi.org/10.3991/ijim.v14i12.15595 \\ Sapto Adi $\left({ }^{\varpi}\right)$, Abi Fajar Fathoni \\ Universitas Negeri Malang, Malang, Indonesia \\ sapto.adi.fik@um.ac.id
}

\begin{abstract}
The students at Sports School are athletes that often leave school for training camps or participate in competitions outside the city. This study therefore, aims to determine the characteristics, conditions, and needs of Sports Schools in Indonesia as a basis for the Blended Learning development. Data were collected on information related to Sports School in various regions of Indonesia, through surveys. The result showed that there are special services for students that participate in training camps and competitions. However, their skill is ineffective and requires an increase in teaching hours and workload. Therefore, based on the characteristics of the Sports School and the needs of teachers and students, the Blended Learning model was developed.
\end{abstract}

Keywords-Needs analysis, blended learning, sports school.

\section{$1 \quad$ Introduction}

In Indonesia, Sports Schools differ from the other educational institutes [1]. However, this school need to adjust their learning curricula by considering or observing the characters of students as sports athletes and their daily activities [2]. In addition to embracing formal education, students-athletes also need to practice and implement a sports coaching program [3].

According to [4], student-athletes are ineffective when enrolled in public schools, despite the addition of sporting activities in their extracurricular activities. This is because general subjects are prioritized over sports, and as the sporting infrastructures available in public schools, are inadequate and below standard [5]. Enrolling athletes in public schools tends to affect their performance in sports. Therefore, based on these problems, the Sports School in Indonesia was established to facilitate education for student-athletes [6].

These problems reappear in the Sports School due to the high demand for success by the student-athletes, and this requires them to exercise harder [7]. It is also not uncommon for students to participate in special exercises or competitions outside the city for quite a long time [8]. This causes the students to be less involved in the general subject learning materials.

The inability to prioritize general subjects at Sports Schools is actually not unreasonable, because the main goal is to facilitate sports achievements [9]. Therefore, it is 
natural that general subjects rank second on the priority list of such institutes, although the knowledge derived from it, is essential and equips the students with life skills after graduation [10].

In dealing with these problems, certain methods are employed to achieve balanced goals, which enable students to excel in the field of sports and also acquire knowledge from general subjects as a life skill after graduation. Therefore, a system that meets both of these students' needs is achievable [11].

Blended learning is developed to enable students to combine face-to-face, offline, online, and mobile learning methods [12]. This type of learning needs to be implemented in Sports School because its characteristics ensure students are able to learn without having to meet directly with the teacher [13]. Students carry out offline, online, and mobile learning anywhere and anytime [14].

Face-to-face learning makes it possible for students to meet with their teachers. The various types of blended learning components aid student athletes to study while participating in training activities or competitions outside the school environment. Therefore, the Blended Learning system is highly recommended and needs to be implemented by Sports Schools in Indonesia.

Subsequently, several factors, such as media facilities and the development of teaching materials, need to be considered during implementation [15]. This is because, in Blended Learning, students need the media and teaching materials in the form of learning videos, electronic books, interactive multimedia, and online quizzes [16]. Therefore, teachers also need to develop teaching materials for students whenever they are leaving for centralized training and competitions outside the city.

According to [17], Blended Learning needs to be carried out in all Sports Schools in the various regions. This is a gradual study that lasts for three years, however, in the first year, the learning needs are analyzed [18]. The needs analysis is used to determine the Sports School ability to use Blended Learning and the abilities of the teacher [19], [20]. Therefore, this article analyzes the needs of Blended Learning in Sports Schools, as well as its needs for future purposes. Training and trials were conducted for teachers in the second year, with an effective test in the third year [21].

\section{$2 \quad$ Method}

This research is divided into three stages. The first stage involves the needs analysis of Blended Learning in Sports Schools. The second stage is the teacher training and trial implementation of Blended Learning. The third stage is the effectiveness test conducted after the implementation of the Blended Learning in Sports Schools. In the first stage, the survey method, which involves the use of questionnaires and direct field observation, was employed during data collection. The questionnaire contains a list of statements that have been validated by experts with data collected from students and teachers.

The survey locations are Sports Schools scattered all over Indonesia. The intended schools are the Palembang Sriwijaya State Sports School in South Sumatra Province, Special Sports Senior High School in South Sulawesi Province, Sports State Senior 
High School in East Java, Ragunan Senior High School in Jakarta, and International Sports School in East Kalimantan Province.

\section{$3 \quad$ Results}

\subsection{Data obtained from the teacher}

According to the analysis conducted on 57 teachers, $96.3 \%$ of teachers had smartphones, $85.2 \%$ had laptops, $7.4 \%$ had LCD projectors, $22.2 \%$ had PCs (personal computers), $51.9 \%$ had printers, $24.1 \%$ had scanners, and $16.7 \%$ had tablets or ipads. The data exposure is shown in Figure 1.

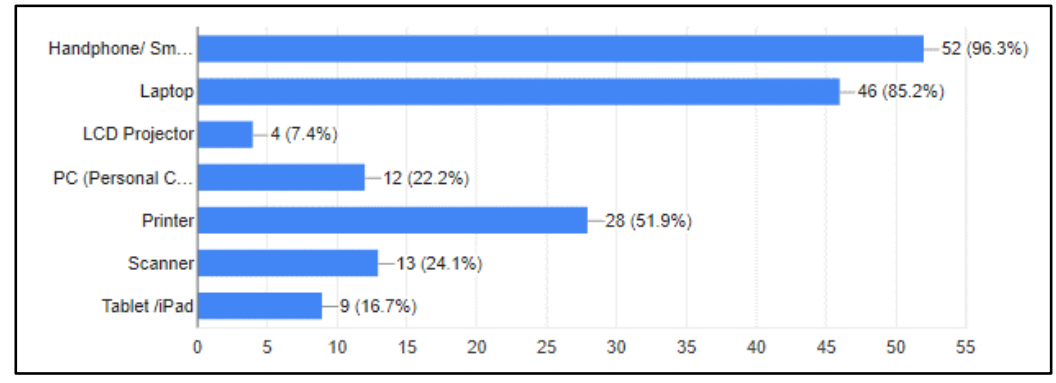

Fig. 1. Data on teacher's personal facilities

Smartphones and laptops are personal devices owned by teachers. Therefore, it is possible to develop various teacher learning competencies by utilizing Information Communication and Technology (ICT), assuming the teacher has the ability to operate a computer (next data) properly.

However, it was observed that during learning implementation, most teachers failed to use laptops to present the subject matter. Meanwhile, the use of smartphones to support this type of learning is lacking because students are prohibited from using it in the school environment. These findings were confirmed by the data obtained from the authors and students. This triggered the author's interest because smartphones are the most widely owned facility, and its utilization in supporting learning is not optimal.

Therefore, it was necessary to obtain data from the learning model used by the teacher. The result showed that $92 \%, 89.1 \%, 60 \%, 40 \%, 34.5 \%, 43.6 \%, 50.9 \%, 10.9 \%$, and $23.6 \%$ of teachers used the lecture, discussion, cooperative, problem, project, independent, classical, anywhere, and Online Learning methods as shown in Figure 2. 


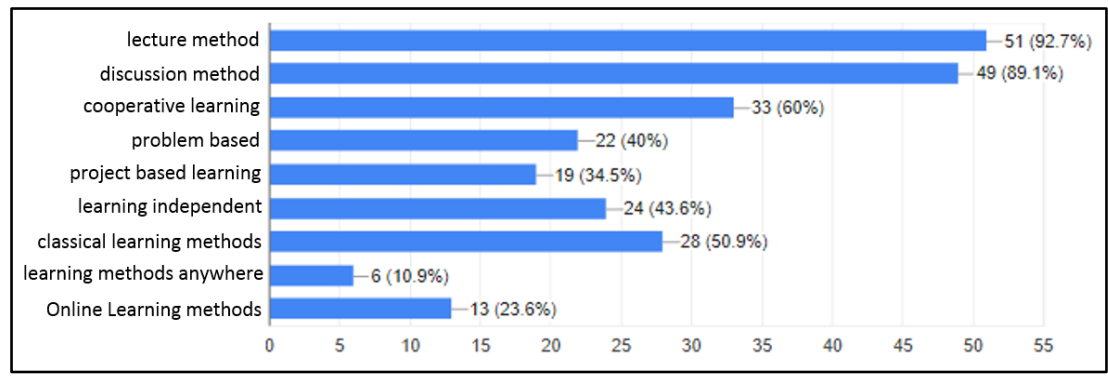

Fig. 2. Learning model used by the teacher

Furthermore, the teacher's fundamental knowledge of Blended Learning is in the following data. The data obtained shows that $37.5 \%$ of teachers were already aware of the term blended learning, $37.5 \%$ had no knowledge of it, and $25 \%$ just learned about the system. Nevertheless, it was discovered that only $37.5 \%$ were aware of the learning process, while the remaining $62.5 \%$ had no knowledge of the system. Therefore, it was concluded that the majority of the teachers are not yet familiar with this type of learning process, as shown in Figure 3.

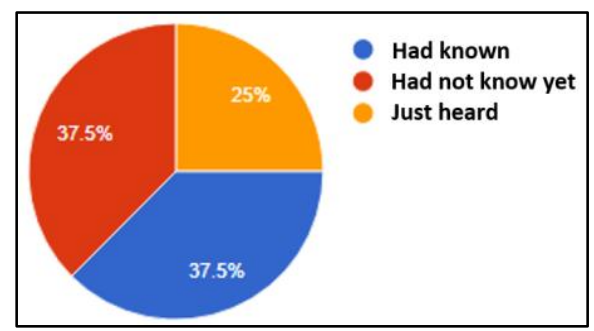

Fig. 3. Teacher knowledge level about blended learning

Subsequently, data obtained from the implemented blended learning shows that $12.5 \%$ out of $37.5 \%$ of the teachers had implemented the process, while $87 \%$ of the total respondents did not, as shown in figure 4.

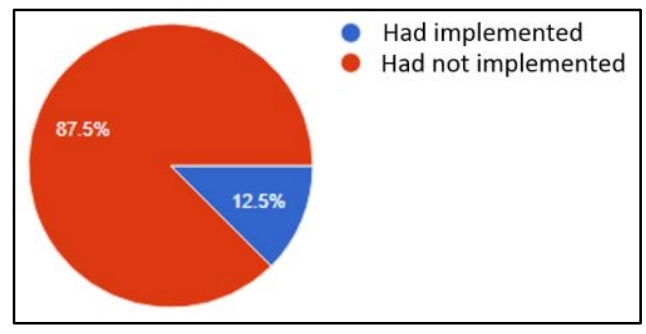

Fig. 4. Data on learning implementation by $37.5 \%$ of teachers familiar with blended learning 
According to the data related to the development of the learning resources, $94.5 \%$ of teachers have developed learning resources, meanwhile, due to certain specific reasons, $5.5 \%$ failed to, as shown in Figure 5.

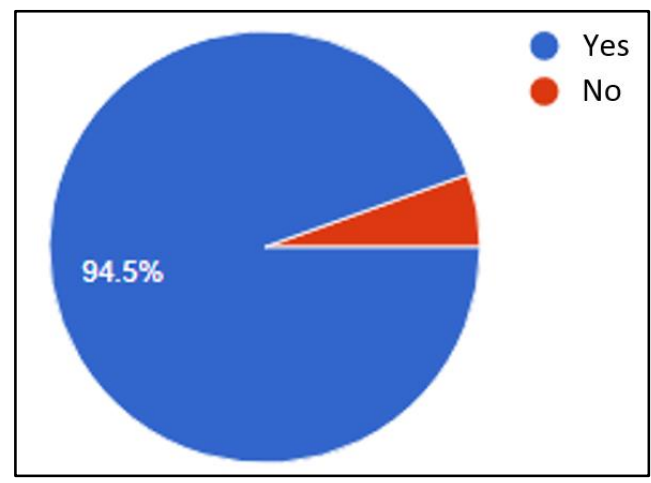

Fig. 5. Data of teachers developing learning resources

Although many teachers have developed learning resources to facilitate students' learning, it is necessary to explore other types of learning resources. Its availability is important in the development of this study, because the characteristics of learning in sports schools are fairly different from public schools, in terms of student activities, class hours and material content. Furthermore, the interviews conducted on teachers, principals, and students, showed that there was a reduction in classroom teaching hours by 10 minutes. Therefore, teachers need to develop learning resources that facilitate students to study outside school hours. According to the data obtained, 80.8\%, $73.1 \%$, $13.5 \%, 28.8 \%, 42.3 \%, 48.1 \%, 17.3 \%, 25 \%, 7.7 \%, 21.2 \%$, and $5.8 \%$ of teachers developed student worksheet learning resources from lesson plans, syllabus or curriculum, collection of chapters/books, textbooks, PowerPoint, audio resources, video learning resources, interactive multimedia, Internet-based and mobile learning based resources, respectively as shown in Figure 6.



Fig. 6. Learning resources data developed by teachers 
According to the above findings, most of the learning resources developed by the teachers are still used to facilitate conventional learning, this means that they are not optimally utilizing the personal facilities.

This, however, led to the development of a blended learning model in accordance with teacher characteristics. The data based on special services for students at the Sports School are shown in figure 7. In accordance with the data, $82.1 \%$ of teachers offered special services to the competing students. Meanwhile, $17.9 \%$ did not provide such services, as shown in Figure 7.

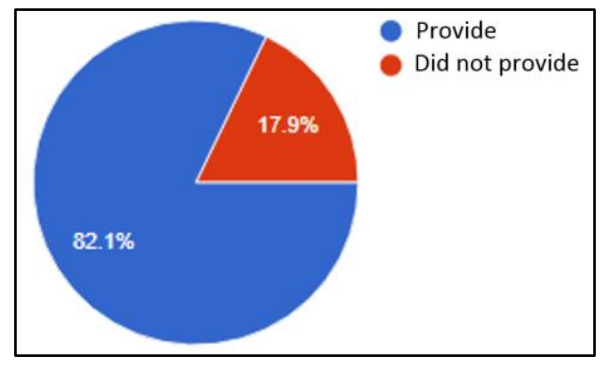

Fig. 7. Percentage of teachers that provided special services for the students

It is important to provide special services to students in sports schools because they are potential athletes, and tend to be absent from class in order to focus on training. The duration of the special services offered to dispensed students is shown in figure 8 . The data shows that, $50 \%$ of teachers started offering special services in the preparation stage, $34.8 \%$ in the pre-match stage, $21.7 \%$ in the match stage, and $69 \%$ in the postmatch stage.

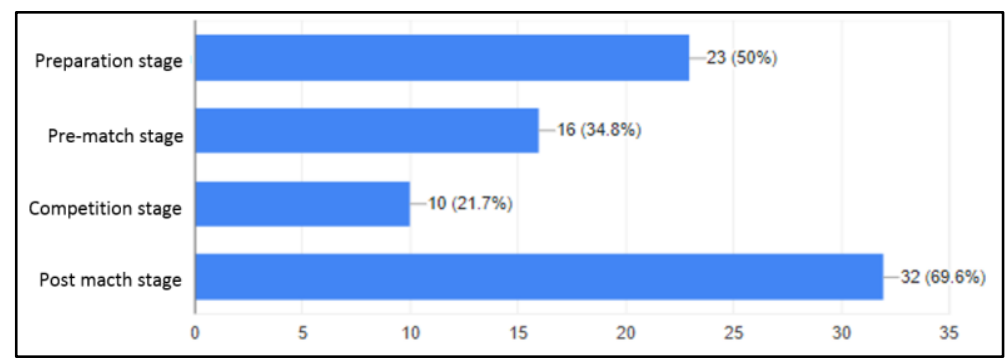

Fig. 8. Percentage of special service time provided by teachers

The types of special services provided by 53 teachers are as follows, $84.9 \%$ gave out independent assignments, $52.8 \%$ provided students worksheets, $22.6 \%$ offered printed modules, $1.9 \%$ used electronic modules, $15.1 \%$ offered services through online classes, $5.7 \%$ provided services with interactive multimedia learning resources, $17 \%$ used powerpoints, $13.2 \%$ employed learning videos, $3.8 \%$ utilized audio learning, $3.8 \%$ applied mobile learning, $1.9 \%$ delivered their services through LMS, $1.9 \%$ via the Internet, and another $1.9 \%$ provided private services. The data is shown in Figure 9. 


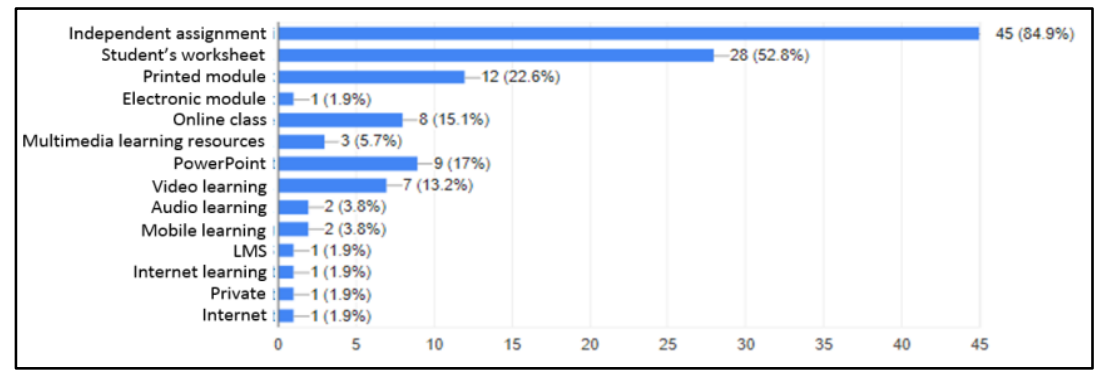

Fig. 9. Percentage of special services provided by teachers

Subsequently, the data based on teachers' ability to use various computer software during learning shows that majority know how to use Microsoft Word and Powerpoint. Furthermore, some do not know how to use interactive e-book creation, screencastOmatic based presentation video creation, autoplay-based interactive multimedia creation, mind manager, and sigil-based mobile learning resource maker software as shown in Figure 10.

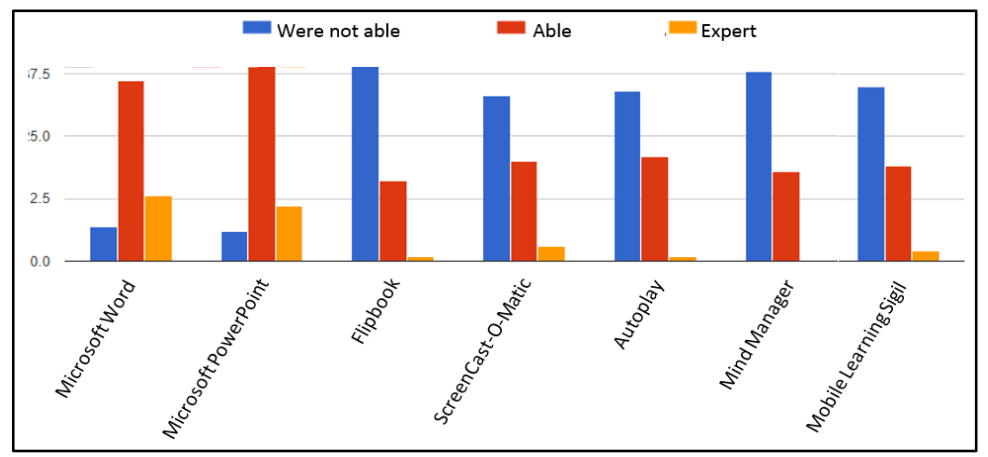

Fig. 10. Data on teacher's ability to use supporting learning software

Finally, the needs analysis in accordance with the development of the blended learning model by teachers in the sports school is stated as follows. Approximately $76 \%$ of teachers agreed to develop a blended learning model in the Sports School, while 19.6\% strongly agreed, and 3.6\% disagreed. The data is shown in Figure 11. 




Fig. 11. Percentage of teachers that agreed to develop blended learning models

\subsection{Data from students}

In addition to the data obtained from teachers, students were also interviewed to fulfill the level of information accuracy. Based on the data obtained from 290 students, $99 \%, 1.7 \%, 2.8 \%, 15.2 \%, 3.1 \%$, and $0.3 \%$ own smartphones, PC computers, tablets, laptops, projectors, printers, and scanners, respectively as shown in figure 12 .

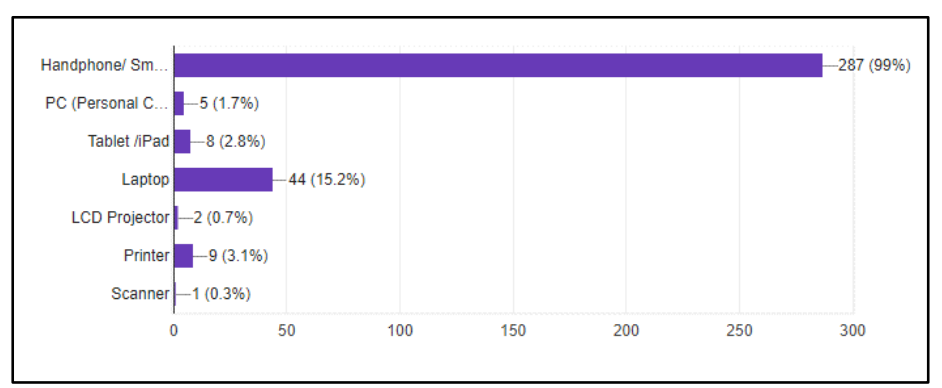

Fig. 12. Data on facilities owned by students

To support the implementation of blended learning, students need to own a laptop, computer, or smartphone. Therefore, the fact that most students do not own these devices needs to be considered when designing learning resources.

Furthermore, data based on students' knowledge of blended learning showed that approximately $47.5 \%$ of the students had never heard the model, while $49.1 \%$ just heard of blended learning. The data is shown in Figure 13. 


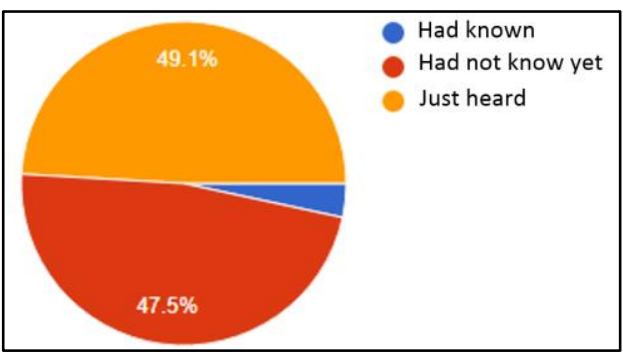

Fig. 13. Percentage of student knowledge about blended learning

According to the data, most students have never heard of the Blended Learning, therefore, it is logical for them not to have carried out the process. Figure 14 show that approximately $97.7 \%$ have never used the blended learning model.

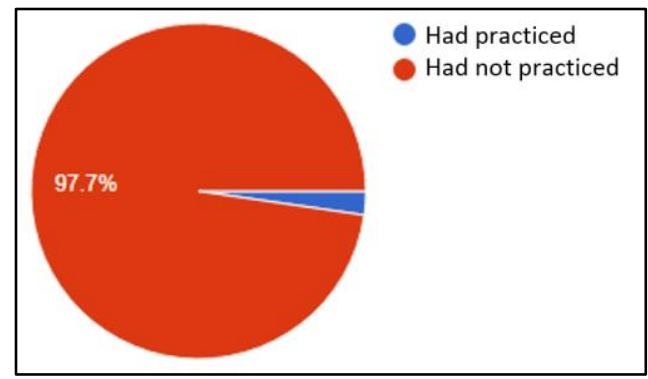

Fig. 14.Percentage of students who practice blended learning

Students' perspective on the characteristics of learning carried out by teachers shows that majority still employed face-to-face and offline learning using printed books. Approximately $10.9 \%$ used online learning, and $12.5 \%$ applied mixed learning. The faceto-face and independent learning conducted with printed books are the primary choices for teachers in implementing blended learning. The data is shown in Figure 15.

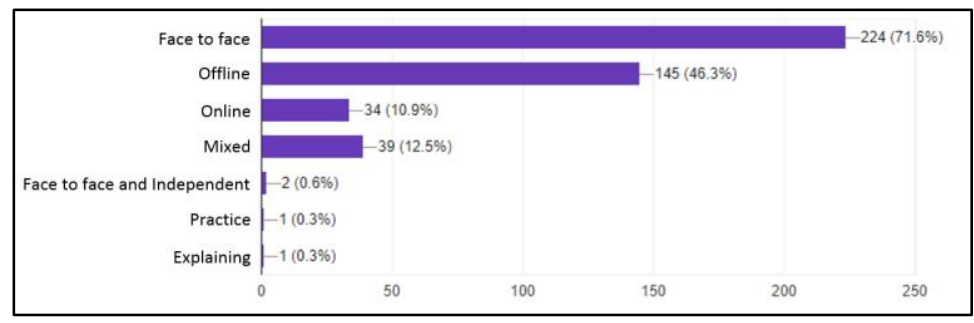

Fig. 15. Data of learning performed by teachers according to students

Figure 16, shows that $93.85 \%$ of the students listened to the teachers' explanations, $65.6 \%$ participated in discussions, $17.8 \%$ practice in the laboratory, $45.6 \%$ learned through printed books, $30.6 \%$ studied independently by using the internet, $53.4 \%$ 
studied in groups, $16.9 \%$ studied in libraries, $16.9 \%$ studied anywhere, $0.3 \%$ engaged in self-tutoring, $0.3 \%$ were tutored, $0.3 \%$ study in religious spaces, $0.3 \%$ usually played with their mobile phones as well as always sleeping, $0.3 \%$ conduct practical work outside the classroom.

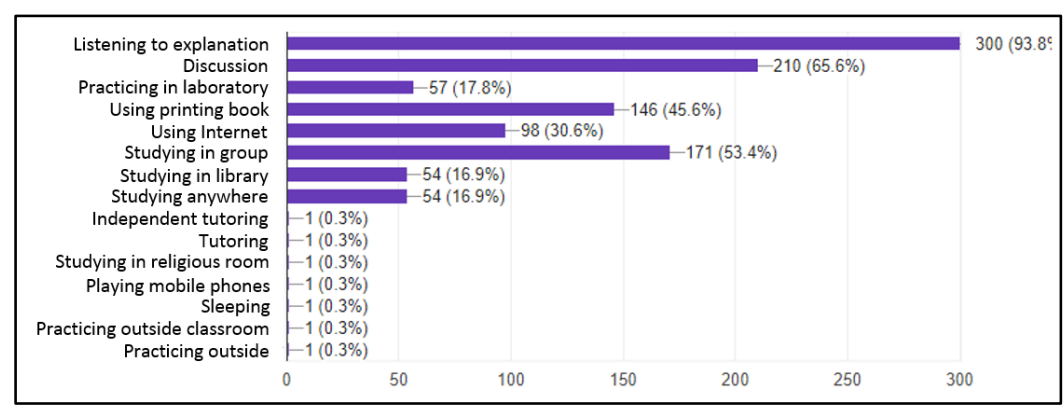

Fig. 16.Percentage of student activities at school

In accordance with the policy relating to students in training camps, it was observed from a total of 310 students, $18.4 \%$ left, $81.3 \%$ received dispensation, $0.3 \%$ were absent, $8.7 \%$ were reported to be present, $7.4 \%$ participated in distance learning, $0.3 \%$ were late for school, and $0.3 \%$ were given permission. This is shown in Figure 17.

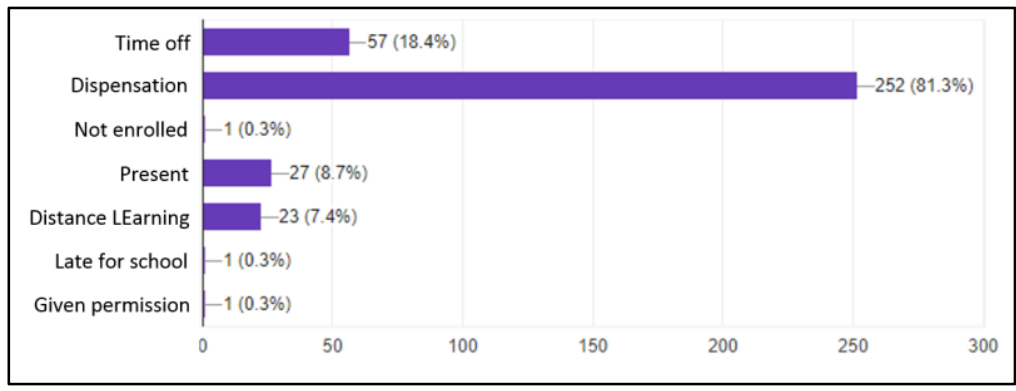

Fig. 17. Data related to the policy when students carry out training camps and competitions

Figure 18, shows that few schools offer distance learning facilities to students in training camps through various forms, namely $32.6 \%$ via email, $25.5 \%$ through telephone, $9.1 \%$ via skype, and $71.3 \%$ through social media. 


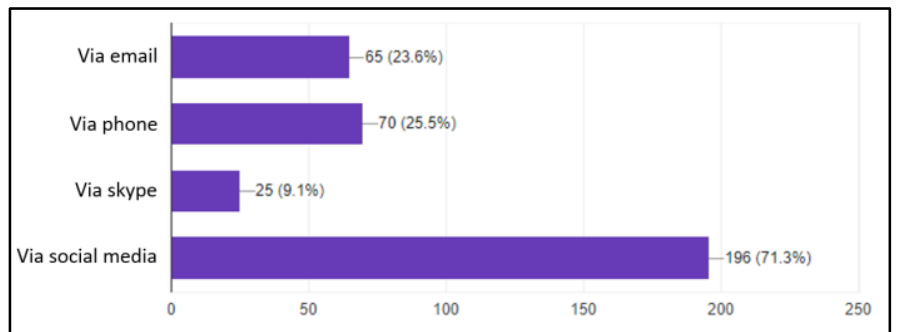

Fig. 18. Percentage of distance learning performed by teachers and students

In order to support independent learning, teachers need to provide additional learning materials. The response from students provided with additional learning materials is as follows $61 \%$ obtained extra learning materials, while $39 \%$ did not get any as shown in Figure 19.

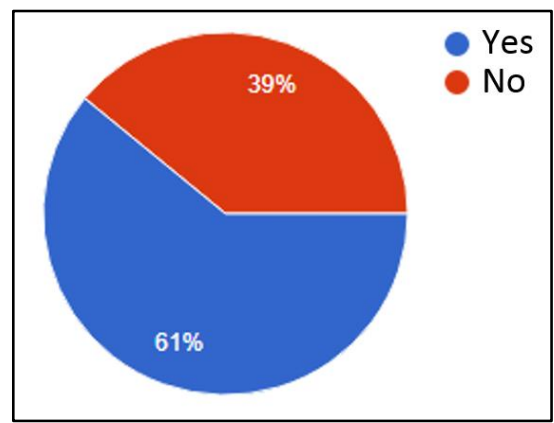

Fig. 19. Data related to additional learning materials from teachers according to students

Figure 20 shows the various types of additional independent learning materials that students obtained from their teachers. A total of $80 \%$ got printed books, $40.4 \%$ obtained powerpoints, $16.8 \%$ received audio materials, $32 \%$ got video learning materials, $30.4 \%$ acquired learning material from the internet, while $6 \%$ benefitted from mobile learning.

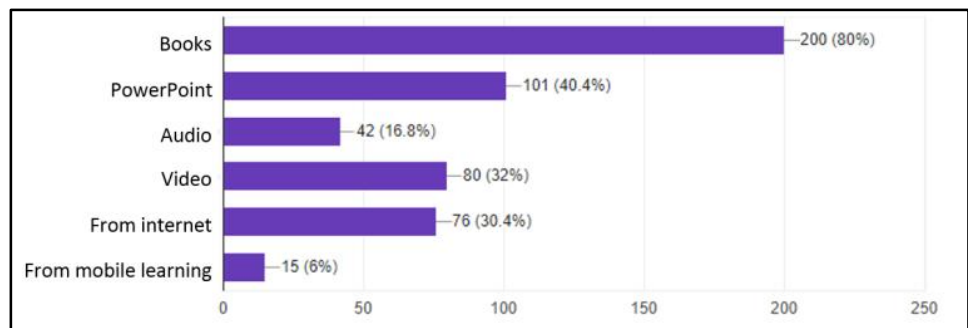

Fig. 20.Percentage of independent learning additional materials provided by teachers

The students' ability to operate software for various learning resources also needs to be retrieved. Most students know how to operate Microsoft Word, PowerPoint, Excel, 
social media applications, computer-based online applications, and Android applications. However, the most common software they found difficult to operate is computerbased online applications (online classes). This data is shown in Figure 21.

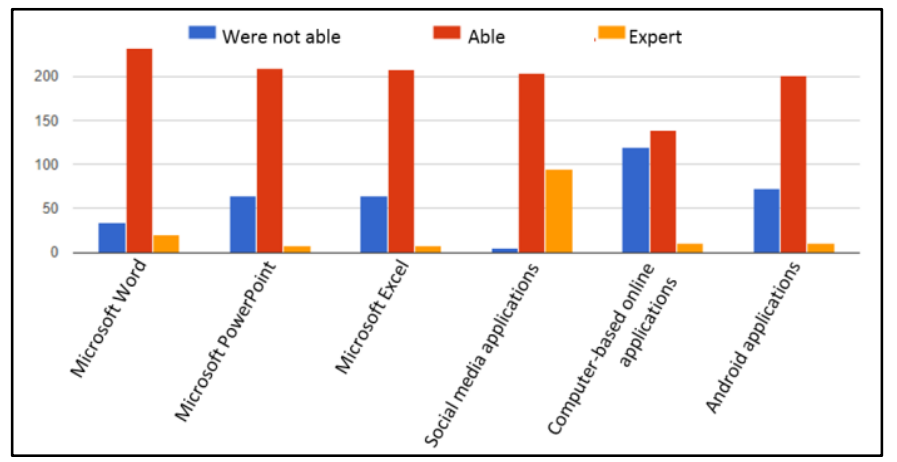

Fig. 21. Data on student ability in operating the learning resource software

Education in Sports Schools mostly employs a dormitory system, therefore various facilities need to be provided for students. However, this study focused on the availability of learning facilities where $61.2 \%, 11.1 \%$, and $35.2 \%$ of the students were given printed, electronic, and interactive multimedia books. as shown in Figure 22.

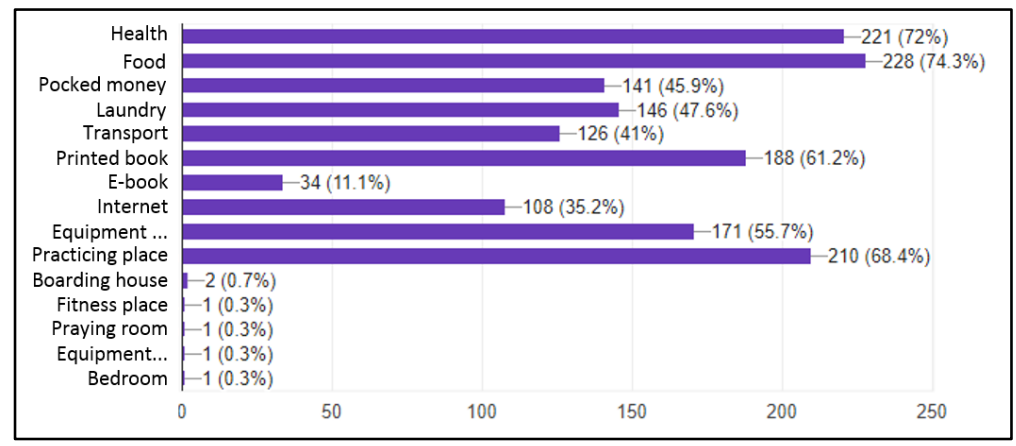

Fig. 22. Data of student facility obtained from schools

Figure 23, shows that after the students received an explanation of blended learning, from a total of 306 students, 54.9 agreed to develop blended learning, while $18.3 \%$ strongly agreed, and $26.8 \%$ disagreed. 


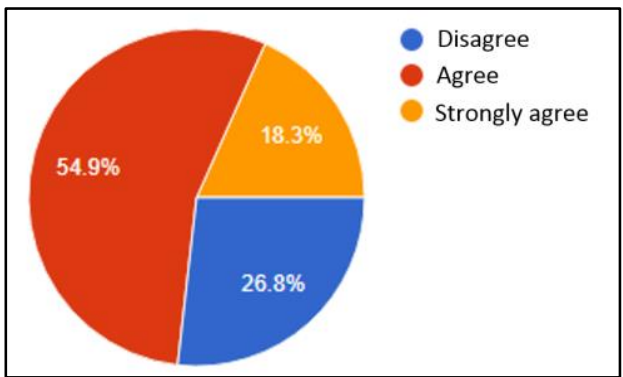

Fig. 23. Percentage of students who agree to develop blended learning

\section{Discussion}

The results showed that the limitations associated with Sports schools in Indonesia, are solved through problem-identification identified [22]. For example, private facilities owned by teachers needs to be used to maximize online and offline learning [23]. According to the data obtained, majority of the teachers have laptops, smartphones, and scanners while some own computers, which are needed to develop learning resources for students. The learning media needs to be developed by considering the effectiveness and efficiency of its application [24].

In addition, data obtained from students showed that majority have private facilities such as smartphones therefore, teachers need to develop learning resources using this device [25], [26].

Based on the condition of the existing analysis, Blended Learning is actually appropriate, assuming it is carried out in the Sports School environment. Therefore, students in training camps or competition outside the city need to utilize online, offline, and mobile learning [27]. Simultaneously, they also tend to access learning resources developed by the teacher [28]. Assuming students are able to operate software that is used for this process, it further strengthens the purpose of implementing Blended Learning.

The associated with sport school is teachers inability to develop learning resources with Blended Learning [29]. However, in this study teachers developed learning resources implemented to support students due to their urge to provide assistance irrespective of the limited devices [30]. Moreover, according to the data obtained in this study, a lot of teachers are not aware of Blended Learning. Therefore, the training carried out in the second year of this research is beneficial and helps them to understand the blended learning [31].

Further studies need to be conducted to outcome the limitations associated with developing Blended Learning in Sports Schools in Indonesia [32]. Teachers and students need cooperation to overcome these limitations [18]. Therefore, their approval was asked for the development of a Blended Learning in the Sports Schools [33]. The authors are optimistic that this learning process is going to be helpful because the Sports School had previously tried to create a service system for their students. According to the data, the teacher also provides services for students in training camps or participating in competitions, therefore, by utilizing the developed system, schools become more 
interesting when assisted by learning resources implemented in supporting media for Blended Learning [34].

\section{Conclusion}

Generally, Sports Schools differ from standard academic institutes. This is because a lot of students need to regulate their time between sports achievements and formal education. Majority do not participate in learning activities at school because they visit training camps or competitions outside the city, which disrupts the learning process, thereby, making it impossible to maximally achieve the general subject matter. In addition, it is useful and equips the students with life skills that aid them whenever they are involved in the community which lead to the development of a Blended Learning in Indonesian Sports Schools.

Schools tend to provide special facilities and services to students before, during, and after they go to training camps or participate in competitions. These services include giving assignments, providing books, and also offering additional class hours when they return to school.

Special service system for students in training camps or participating in competitions needs to be implemented. The service is more effective, efficient, and practical, assuming it is supported by Blended Learning. Students utilize online, offline, or even mobile learning. Therefore, by providing support to Blended Learning, they realize learning resources packaged in interesting media, easy to use, and employ irrespective of the time and place.

\section{References}

[1] J. A. Rosenthal, R. E. Foraker, C. L. Collins, and R. D. Comstock, "National high school athlete concussion rates from 2005-2006 to 2011-2012," Am. J. Sports Med., 2014. https://doi.org/10.1177/0363546514530091

[2] J. M. Thein-Nissenbaum and K. E. Carr, "Female athlete triad syndrome in the high school athlete," Phys. Ther. Sport, 2011. https://doi.org/10.1016/j.ptsp.2011.04.002

[3] D. Sugimoto et al., "Preventive Neuromuscular Training for Young Female Athletes: Comparison of Coach and Athlete Compliance Rates," J. Athl. Train., 2017.

[4] M. E. Taylor and J. E. Sanner, "The Relationship Between Concussion Knowledge and the High School Athlete's Intention to Report Traumatic Brain Injury Symptoms: A Systematic Review of the Literature," J. Sch. Nurs., 2017. https://doi.org/10.1177 $\underline{1059840515619683}$

[5] M. Marar, N. M. Mcllvain, S. K. Fields, and R. D. Comstock, "Epidemiology of concussions among united states high school athletes in 20 sports," Am. J. Sports Med., 2012. https://doi.org/10.1177/0363546511435626

[6] J. K. Register-Mihalik, K. M. Guskiewicz, T. C. V. McLeod, L. A. Linnan, F. O. Mueller, and S. W. Marshall, "Knowledge, attitude, and concussion-reporting behaviors among high school athletes: A preliminary study," J. Athl. Train., 2013. https://doi.org/10.4085/ $\underline{1062-6050-48.3 .20}$ 
[7] S. P. Broglio, J. T. Eckner, and J. S. Kutcher, "Field-based measures of head impacts in high school football athletes," Current Opinion in Pediatrics. 2012. https://doi.org/10.1097/mop.0b013e3283595616

[8] W. P. Meehan, P. D'Hemecourt, C. L. Collins, and R. D. Comstock, "Assessment and management of sport-related concussions in United States high schools,” Am. J. Sports Med., 2011. https://doi.org/10.1177/0363546511423503

[9] D. C. Funk, A. D. Pizzo, and B. J. Baker, "eSport management: Embracing eSport education and research opportunities," Sport Management Review. 2018. https://doi.org/10.1016 /j.smr.2017.07.008

[10] D. E. Hendrianto, "Pembuatan Sistem Informasi Perpustakaan Berbasis Website Pada Sekolah Menegah Pertama Negeri 1 Donorojo Kabupaten Pacitan," IJNS-Indonesian J. Netw. Secur. ISSN 2302-5700 2354-6654 (Online, 2014.

[11] A. Lavalle and O. Casale, "Project Managers Are the Best Candidates to Manage Innovation," Int. J. Adv. Corp. Learn., 2020. https://doi.org/10.3991/ijac.v13i1.12357

[12] H. Staker and M. B. Horn, "Classifying K-12 Blended Learning," Innosight Inst., 2012.

[13] S. Tyley, "Blended learning," Fire Risk Manag., 2012.

[14] M. Friedl, M. Ebner, and M. Ebner, "Mobile Learning Applications for Android und iOS for German Language Acquisition based on Learning Analytics Measurements,” Int. J. Learn. Anal. Artif. Intell. Educ., 2020. https://doi.org/10.3991/ijai.v2i1.12317

[15] E. R. Kahu, "Framing student engagement in higher education," Stud. High. Educ., 2013.

[16] M. Tubagus, S. Muslim, and S. Suriani, "Development of Learning Management SystemBased Blended Learning Model using Claroline in Higher Education," Int. J. Interact. Mob. Technol., 2020. https://doi.org/10.3991/ijim.v14i06.13399

[17] R. Owston, D. York, and S. Murtha, "Student perceptions and achievement in a university blended learning strategic initiative," Internet High. Educ., 2013. https://doi.org/10.1016 /j.iheduc.2012.12.003

[18] S. Jamshed, "Qualitative research method-interviewing and observation," J. Basic Clin. Pharm., 2014.

[19] A. Ghofar and S. M. N. Islam, "Research method," in Contributions to Management Science, 2015.

[20] M. Tight, P. Symonds, and P. M. Symonds, "The Case Study as a Research Method," in Case Studies, 2016.

[21] S. Yeasmin and K. Rahman, “'Triangulation' Research Method as the Tool of Social Science Research,” Bup J., 2012.

[22] D. A. Story and A. R. Tait, "Survey Research," Anesthesiology, 2019.

[23] S. Adi and A. F. Fathoni, "The effectiveness and efficiency of blended learning at sport schools in Indonesia," Int. J. Innov. Creat. Chang., 2020.

[24] W. D. Dwiyogo and C. L. Radjah, "Effectiveness, efficiency, and instruction appeal of blended learning model," Int. J. Recent Technol. Eng., 2019. https://doi.org/10.37200 lijpr/v24i2/pr200552

[25] M. Sharples and R. Pea, "Mobile learning," in The Cambridge Handbook of the Learning Sciences, Second Edition, 2014.

[26] J. Gikas and M. M. Grant, "Mobile computing devices in higher education: Student perspectives on learning with cellphones, smartphones \& social media," Internet High. Educ., 2013. https://doi.org/10.1016/j.iheduc.2013.06.002

[27] Y. T. Sung, K. E. Chang, and T. C. Liu, "The effects of integrating mobile devices with teaching and learning on students' learning performance: A meta-analysis and research synthesis," Comput. Educ., 2016. https://doi.org/10.1016/j.compedu.2015.11.008 
[28] A. F. Fathoni, "The Role of Blended Learning on Cognitive Step in Education of Sport Teaching by Adjusting the Learning Style of the Students," 2018. https://doi.org/10.2991 lisphe-18.2018.49

[29] N. Dabbagh and A. Kitsantas, "Personal Learning Environments, social media, and selfregulated learning: A natural formula for connecting formal and informal learning," Internet High. Educ., 2012. https://doi.org/10.1016/j.iheduc.2011.06.002

[30] V. Kumar and P. Nanda, "Social Media in Higher Education," Int. J. Inf. Commun. Technol. Educ., 2018.

[31] M. Walenta, "Research method," in Second Language Learning and Teaching, 2019.

[32] H. Staker and M. B. Horn, "Classifying K - 12 blended learning," 2012.

[33] G. J. Skulmoski, F. T. Hartman, and J. Krahn, "The Delphi Method for Graduate Research," J. Inf. Technol. Educ. Res., 2017.

[34] F. M. Aldhafeeri, "Blended learning in higher education," in International Handbook of ELearning Volume 2: Implementation and Case Studies, 2015.

\section{Authors}

Dr. Sapto Adi, M.Kes is the Dean of the Faculty of Sport Science, State University of Malang, Indonesia. His research is in the field of sports achievement with interests in schools, sports clubs, organizations, and higher education. Email: sapto.adi.fik@um.ac.id, ORCID ID: https://orcid.org/0000-0001-6801-524X

Abi Fajar Fathoni, S.Pd., M.Pd is a staff of the Faculty of Sports Science, Malang State University, Indonesia. His research is in the use of technology in sports education, its management, and contribution to the nation. Email: fajarfathoniabi@gmail.com, ORCID ID: https://orcid.org/0000-0003-2963-2418

Article submitted 2020-05-04. Resubmitted 2020-05-29. Final acceptance 2020-05-29. Final version published as submitted by the authors. 